\title{
Laboreal
}

Volume $16 \mathrm{~N}^{\circ} 2$ | 2020

Programa de Pesquisa do Curso da Ação

\section{Grupos de Implicação e Pesquisa e Organidrama como dispositivos de pesquisa e intervenção no mundo do trabalho}

Grupos de Implicación e Investigación y Organidrama como dispositivos de investigación e intervención en el mundo del trabajo

Groupes d'Implication et de Recherche et Organidrame comme dispositifs de recherche et d'intervention dans le monde du travail

Implication and Research Groups and Organidrama as devices for Research and Intervention in the working world

\section{Matheus Viana Braz e Francisco Hashimoto}

\section{(2) OpenEdition}

\section{Journals}

\section{Edição electrónica}

URL: http://journals.openedition.org/laboreal/17128

DOI: $10.4000 /$ laboreal. 17128

ISSN: 1646-5237

\section{Editora}

Universidade do Porto

\section{Refêrencia eletrónica}

Matheus Viana Braz e Francisco Hashimoto, « Grupos de Implicação e Pesquisa e Organidrama como dispositivos de pesquisa e intervenção no mundo do trabalho », Laboreal [Online], Volume 16 N² I 2020, posto online no dia 01 dezembro 2020, consultado o 13 dezembro 2020. URL : http:// journals.openedition.org/laboreal/17128; DOI : https://doi.org/10.4000/laboreal.17128

Este documento foi criado de forma automática no dia 13 dezembro 2020

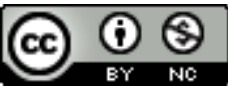

Laboreal está licenciado com uma Licença Creative Commons - Atribuição-NãoComercial 4.0 Internacional. 


\section{Grupos de Implicação e Pesquisa e Organidrama como dispositivos de pesquisa e intervenção no mundo do trabalho}

Grupos de Implicación e Investigación y Organidrama como dispositivos de investigación e intervención en el mundo del trabajo

Groupes d'Implication et de Recherche et Organidrame comme dispositifs de recherche et d'intervention dans le monde du travail

Implication and Research Groups and Organidrama as devices for Research and Intervention in the working world

Matheus Viana Braz e Francisco Hashimoto

\section{NOTA DO EDITOR}

Manuscrito recebido em : 24.03.2020

Aceite após peritagem : 02.10.2020

\section{Introdução}

1 Nos anos de 1980, a consolidação da Revolução Digital foi acompanhada do tensionamento dos padrões de produção tayloristas e fordistas pela emergência do Toyotismo. A escalada da automatização dos processos produtivos e as mudanças nos marcadores de competição entre as organizações, no contexto da universalização das redes eletrônicas e da informação, se assentaram mediante um cenário global no qual as finanças e os mercados se interconectam em tempo real, o que produziu 
metamorfoses substanciais no mundo do trabalho (Gaulejac \& Hanique, 2015 ; Viana Braz, 2019).

Confrontados com o declínio da sociedade salarial e constantemente preocupados com a empregabilidade, os trabalhadores passaram a sofrer também os efeitos deletérios da pulverização das fronteiras entre atividade laboral e vida privada, da urgência do tempo e da densificação das jornadas de trabalho (Gaulejac \& Hanique, 2015 ; Viana Braz, 2019). Com efeito, no contexto da descartabilidade e da instabilidade profissional, intensificam-se as pressões, as exigências de desempenho e a competitividade em nossa sociedade. Quando surgem conflitos ou carga significativa de sofrimento nos espaços de trabalho, revelam-se predominantes dois tipos de respostas : indica-se a procura por médicos, psicólogos e demais profissionais especialistas e encarregados de mitigar o sofrimento humano ou, mais comum em empresas, convocam-se consultores especializados em desenvolvimento organizacional, encarregados de gerenciar os conflitos para colocá-los a serviço da rentabilidade da organização (Gaulejac \& Hanique, 2015). Embora cada uma dessas iniciativas tenha sua efetividade e êxito, possuem limitações para se chegar à origem dos conflitos, amiúde vinculados à conflitos não resolvidos no bojo das organizações. Incorre-se no risco, portanto, da individualização dos conflitos ou da psicologização de contradições institucionais (Gaulejac \& Hanique, 2015).

3 Neste reduto, o arcabouço teórico-metodológico da Sociologia Clínica oferece uma terceira via de ação, que auxilia pesquisadores a intervirem no mundo do trabalho de forma sistêmica, mediante a análise das múltiplas faces dos conflitos que emergem nos grupos, compreendidas na articulação dialética de registros econômicos, sociais, institucionais e existenciais. Ao passo que se distancia de abordagens patologizantes, totalizantes e adota uma postura sensível sobre a subjetividade e o sofrimento psíquico, ela se propõe a fazer uma clínica do social, distanciando-se das práticas analíticas centradas tão somente no indivíduo, inserido em dispositivos particulares (Lhuilier, 2011). Ao se servir de uma matriz pluridisciplinar, entende-se que os processos psíquicos não bastam para compreender o sujeito em situação. Para tanto, é preciso considerar as dinâmicas, relações, vínculos e imaginários sociais coletivos, ademais de uma ampla gama de fenômenos (do intersubjetivo ao societal), que demandam uma óptica sensível em relação aos processos de exclusão, cristalização, alienação, dominação e instrumentalização, juntamente às relações de conflito, solidariedade, confiança, estima e emancipação (Viana Braz, 2019).

O objeto do presente trabalho surgiu atrelado à tese de doutoramento de um dos autores deste manuscrito. Como membro do Réseau International de Sociologie Clinique (RISC), o pesquisador realizou na França as formações acerca dos dispositivos de pesquisa e intervenção da Sociologia Clínica e, logo, se aprofundou na análise dos Grupos de Implicação e Pesquisa (GIP) e do Organidrama enquanto instrumentos de investigação do mundo do trabalho atual. A partir de uma perspectiva compreensiva, tais ferramentas parecem representar alternativas profícuas no processo de exploração das relações entre os conflitos vividos no espaço de trabalho e as contradições existentes nas organizações (Gaulejac, 1999). Nessa esteira, pretende-se neste estudo responder a algumas interrogações : Como são operacionalizados os dispositivos de pesquisa $e$ intervenção da Sociologia Clínica? Quais seus enquadres e pressupostos teóricometodológicos? Quais suas efetivas contribuições às análises dos conflitos vivenciados no trabalho em nossa sociedade? 
5 No âmbito metodológico, a pesquisa foi realizada se utilizando de abordagem qualitativa, transversal e descritiva (Turato, 2003). Ao passo que intervenção e pesquisa são indissociáveis na Sociologia Clínica, este estudo se inscreve na modalidade de pesquisa em serviço (Turato, 2003). Trata-se de uma produção de conhecimento que se dá a partir das atividades profissionais desenvolvidas pelos pesquisadores e, neste caso, essa produção foi fruto da experiência dos autores em intervenções realizadas em diferentes contextos de trabalho no Brasil. A pesquisa em serviço não dispensa o rigor das pesquisas acadêmico-científicas e tampouco se opõe a elas, mas tem como finalidade o aprofundamento de entraves e obstáculos encontrados na prática dos profissionais (Turato, 2003).

6 Há escassos relatos na literatura do idioma português (Takeuti, 2009; Castro \& Guerrero, 2013 ; Nunes \& Silva, 2018) sobre o Organidrama e os Grupos de Implicação e Pesquisa e, dentre eles, nenhum realiza uma análise pormenorizada dos pressupostos e enquadres metodológicos desses dispositivos. Neste trabalho, pretende-se contribuir para a consolidação desse campo de estudos, dando visibilidade a um arcabouço teórico, técnico e metodológico que convida o pesquisador a ser mais sensível ao sofrimento no trabalho, para além do realismo econômico. Seu diferencial reside na superação do paradigma hegemônico e individualizante de intervenção, pelo fato que as intervenções em situações de mal-estar, conflitos e sofrimento no trabalho se dão condicionalmente em grupo e/ou no espaço laboral, o que permite que sejam trabalhados fenômenos de ordem familiar, social e existencial, mas também políticos, ideológicos e gestionários.

\section{Grupos de implicação e pesquisa (gip)}

7 Tanto os GIP quanto o Organidrama se consolidaram como dispositivos de intervenção e pesquisa na década de 1990, no seio do Institut International de Sociologie Clinique (IISC), com apoio do Laboratoire de Changement Social da Université Paris Diderot VII, à época dirigido por Vincent de Gaulejac (Nunes \& Silva, 2018). Os GIP, contudo, precedem o Organidrama. Sua criação foi iniciada por Gaulejac, junto a Michel Bonetti e Jean Fraisse nos anos de 1970 (Gaulejac, 1987). Nas décadas seguintes, esse dispositivo foi enfim lapidado e aperfeiçoado, mediante um trabalho que envolveu pesquisadores de diversos países (Gaulejac, 1999). Segundo Gaulejac (1987), os GIP possuem um duplo objetivo :

- Objetivo de pesquisa e compreensão, que consiste em elaborar um método de investigação que permita analisar e articular fatores sociológicos e psicológicos condicionantes das histórias individuais.

- Objetivo de formação, cujo propósito é oferecer aos participantes suportes de reflexão que lhes possibilitem compreender suas trajetórias sociais e as relações com cada história de vida trabalhada.

8 Enquanto dispositivo privilegiado para análise do trabalho, sua operacionalização se dá em dois níveis. $O$ primeiro remete à expressão e descrição das experiências vividas, a partir da história de vida de cada participante. O segundo, cuja finalidade é analítica, implica a reflexão e elaboração de hipóteses interpretativas sobre os conteúdos trabalhados (Gaulejac, 1999).

9 A qualidade do trabalho realizado depende do grau de implicação dos participantes do grupo. A mobilização dos indivíduos e do interventor facilita a análise dos conteúdos emergentes. Logo, para fazer o trabalho de mediação de um grupo, faz-se necessário 
que o interventor tenha feito à formação em Sociologia Clínica e, consequentemente, que tenha participado de outros grupos, na condição de participante e, depois, de aprendiz. Portanto, o sujeito em formação também realiza um trabalho de exploração, assimilação e elaboração das contradições e conflitos que atravessam sua história de vida.

10 Tal como concebidos em sua origem, os GIP são mediados por dois interventores, com formações de bases distintas. Gaulejac (1987) defende que a co-mediação é um recurso para fomentar visões distintas sobre diferentes fatores (ideológicos, econômicos, históricos e psicológicos) que emergem nos grupos. Quando dois interventores fazem a mediação conjunta, o autor (Gaulejac, 1987) afirma que há uma dinâmica constante de complementaridade e de oposição entre os mediadores, a qual permite que os participantes sejam colocados em uma relação de constante tensão reflexiva. Os autores que subscrevem este estudo, contudo, conduziram variados grupos nos últimos anos com somente um mediador e não foram constatados impedimentos significativos. Embora haja relativa limitação da pluralidade de perspectivas disciplinares envolvida no grupo, conseguiu-se operacionalizar os dispositivos de forma exitosa, sobretudo no que diz respeito aos movimentos analíticos dos grupos e de elaborações, individuais como coletivas.

11 O trabalho sobre as histórias de vida tem por finalidade integrar a relação do passado do indivíduo com seu presente, de modo a abrir novas possibilidades de futuro. 0 dispositivo se serve de suportes verbais e não verbais que favorecem a exploração, implicação e expressão de vivências e emoções individuais (Gaulejac, 1987). 0 elemento grupal dá aos participantes segurança e confiança, mediante identificações projetivas que emergem no grupo e que atuam como mote propulsor do trabalho coletivo de elaboração de hipóteses explicativas (Gaulejac, 1996).

Os Grupos de Implicação e Pesquisa são restritos, entre quatro e doze pessoas, ocorrem ao longo de dois ou três dias (oito horas em média por dia) consecutivos e se voltam a um tema específico, comum a todos os integrantes. Em um primeiro momento, os participantes se apresentam e dizem o que os trouxe até ao grupo. Depois, o interventor contextualiza a abordagem e os objetivos do grupo [1]:

- Trata-se de explorar em que medida a história individual de cada pessoa é socialmente determinada e visa-se compreender como o tema do grupo influencia a história de cada participante. Parte-se da premissa que a história de vida de cada um é produto de fatores psicológicos, sociais, ideológicos e culturais (Gaulejac, 1999), de modo que se busca colocar esses operadores em interação, coletivamente.

O trabalho do grupo é ainda realizado em algumas etapas (Gaulejac, 1987,pp. 299-300) :

- Trabalho sobre a genealogia familiar: foco nas heranças afetivas, econômicas, culturais e ideológicas recebidas por cada integrante.

- Trabalho sobre a formação do "projeto parental" : foco nas projeções, desejos, contradições e incoerências da constituição de cada participante.

- Trabalho sobre o romance familiar : realização de um trabalho (escrito ou verbal), em que cada participante tem a possibilidade de reescrever sua história e a história de sua família, assimilando a construção de sua historicidade.

- Trabalho sobre as "escolhas e rupturas" : foco nas escolhas profissionais, ideológicas, amorosas, pessoais e rupturas familiares, de modo a compreender os elementos estruturantes de sua trajetória social, assim como para apreender como se dá o processo de construção de sua identidade narrativa. 
14 interventor conta com uma série de ferramentas metodológicas que garantem a alternância entre expressão verbal e não verbal das situações evocadas : desenhos sobre o projeto parental, reconstrução de árvores genealógicas, esquema de análise das trajetórias sociais e da identidade socioeconômica, Sociodrama (Moreno, 1978 ; AncelinSchutzenberger, 2003) e Teatro-Fórum (Boal, 1975; Badache, 2015). O objetivo é favorecer as expressões subjetivas, garantir a implicação e a análise coletiva dos aspectos comuns ao grupo (Gaulejac, 1987).

onstrução da árvore genealógica consiste na orientação para que cada sujeito, em uma folha em branco, reconstitua sua genealogia familiar, indicando os nomes das pessoas, profissões, aspectos culturais, momentos e lugares de morte e nascimento, bem como outros traços particulares, como frases marcantes, características físicas, de personalidades, qualidades e, inclusive, eventuais doenças que tiveram pertinência em relação a suas histórias de vida. Indica-se que cada participante faça esse trabalho a partir das últimas três ou quatro gerações. Depois, cada pessoa faz a apresentação de sua genealogia e a discute com o grupo. Esse recurso possibilita a identificação e reflexão sobre as estruturas e heranças familiares, não somente pelas informações transcritas nas folhas, como também pelos vazios encontrados eventualmente nas narrativas dos sujeitos. Cumpre sublinhar que a utilização que a Sociologia Clínica faz desse suporte metodológico é diferente daquela feita nas terapias familiares sistêmicas. Nestas, concebe-se que o genograma traduz o espaço familiar intrapsíquico, como se na folha fosse projetada uma representação da família, tomada quase que exclusivamente em sua dimensão psicológica. Na abordagem clínica, em contraposição se busca apreender também dados objetivos sobre a genealogia familiar do indivíduo, com atenção especial para como a dimensão sócio-histórica condiciona suas escolhas e valores (Gaulejac, 1987). Ao não se restringir à dimensão psicológica, utiliza-se esse recurso para compreender também as interações sociais que se encontram no núcleo da dinâmica familiar.

O projeto parental faz referência às projeções e modelos que são transmitidos pelas figuras paterna e materna (ou outras marcantes). Desde Freud, se reconhece que mesmo antes de seu nascimento o indivíduo já é herdeiro das expectativas e desejos (amiúde inconscientes) de seus pais (Gaulejac, 1999). Enquanto suporte metodológico, a Sociologia Clínica se serve de um recurso projetivo para explorar as nuances dessas transmissões. Orientam-se os participantes do grupo a fazerem dois desenhos, vinculados a duas questões respectivamente: o que meus pais gostariam que eu me tornasse? e 0 que eu me tornei [2]. Para tanto, o mediador deve oferecer ao grupo canetas hidrográficas, lápis e gizes coloridos, dentre outros materiais que facilitem a expressão gráfica. Os desenhos são então dispostos na sala e, primeiro, os participantes do grupo descrevem o que estão vendo. Aqui, trata-se de um trabalho descritivo e não interpretativo do coletivo. Depois desses comentários, o autor apresenta aos demais o que tentou exprimir em seus trabalhos. Ao contrário da reconstrução da árvore genealógica, esse suporte se endereça à expressão e compreensão das representações que cada indivíduo faz de seus respectivos projetos parentais. Portanto, a elaboração de sentido é sempre construída posteriormente, mediante atribuições do próprio sujeito sobre suas projeções. Já no terceiro momento, os membros do grupo reagem sobre os comentários, imagens, apresentações e se coloca em discussão as contradições, 
sentimentos, emoções, pontos compartilhados e divergências que emergiram no trabalho grupal (Gaulejac, $1987 ; 1999$ ).

Como o trabalho sobre o projeto parental remete a dimensão sócio-afetiva dos participantes, a análise do esquema das trajetórias sociais facilita a compreensão das inter-relações entre os contornos identitários herdados e as posições sociais conquistadas. Na prática, essa atividade costuma ser conjugada com a reconstrução da árvore genealógica, mas essa vinculação é opcional, dependendo do tema trabalhado e das estratégicas elencadas pelo mediador. Para tanto, delimita-se um esboço (Figura I) que constitui um eixo norteador, na qual cada participante constrói um esquema em uma cartolina sobre sua genealogia familiar e trajetória social (Gaulejac, 1987).

Figura 1 : Esquema de Análise de uma Trajetória Social. Traduzido e adaptado de Gaulejac (1987/2016, p. 309).

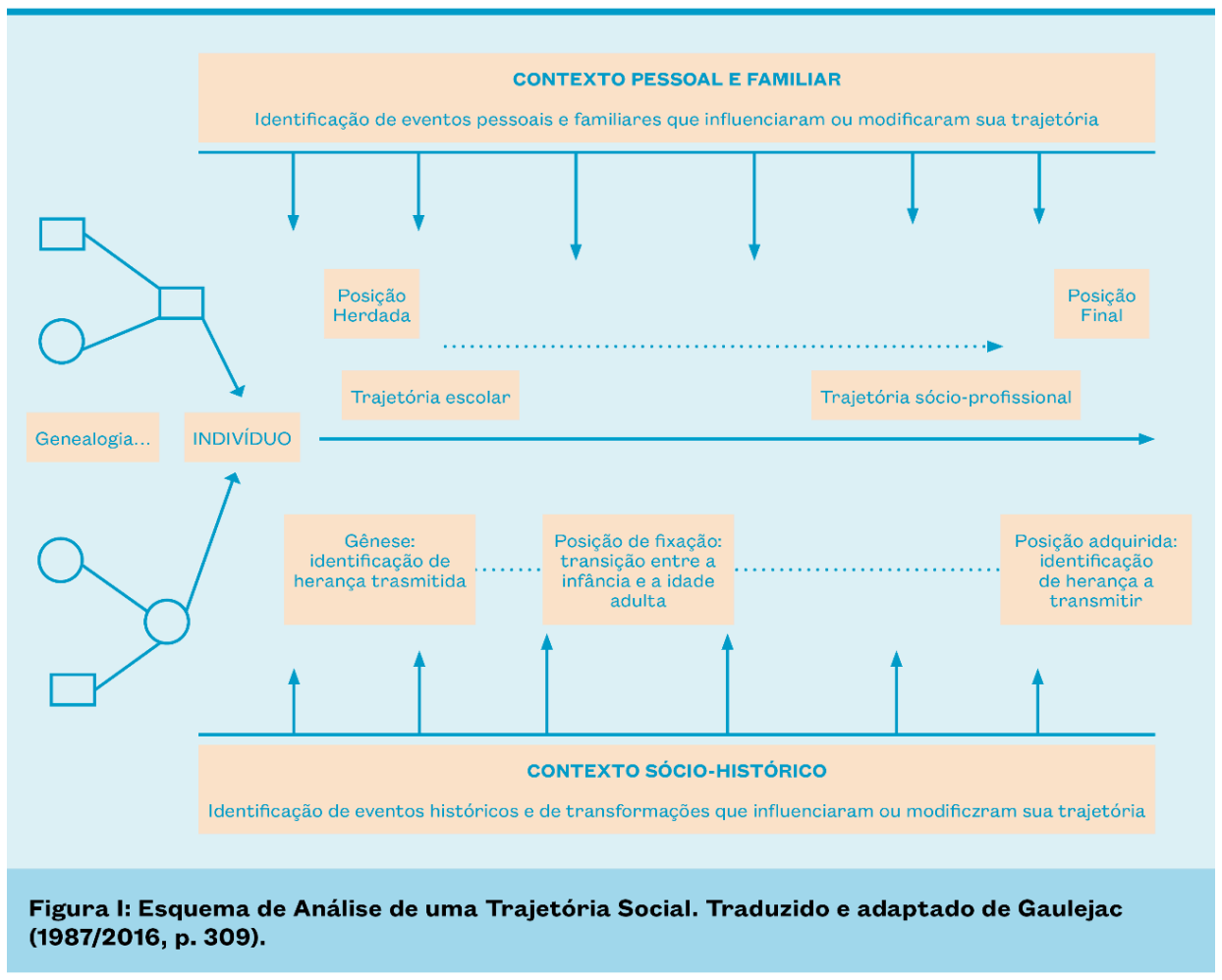

Figura 1 : Esquema de Análise de uma Trajetória Social. Traduzido e adaptado de Gaulejac (1987/2016, p. 309).

o quadro apresentado está didaticamente organizado, porém não há regras cristalizadas quanto a sua formatação. Contando que os elementos destacados estejam presentes, fica a critério de cada sujeito escolher como quer dispor graficamente (na forma de desenho ou escrita) o esquema de sua trajetória social. Após a finalização dessa reconstituição, instruem-se os participantes a colarem suas respectivas cartolinas nas paredes da sala onde ocorre o grupo. Depois, cada indivíduo constrói sua narrativa de vida e a expõe para os demais, que por sua vez podem colocar questões, tanto a quem está apresentando sua história quanto aos outros participantes. Igualmente, o mediador também pode fazer o mesmo, além de ficar responsável pela articulação dos elementos trabalhados. É importante que esse mediador fique atento para que as discussões não sejam endereçadas a um trabalho de escuta individualizante (Gaulejac, 1996). Ao contrário, deve-se buscar a compreensão sobre como os aspectos trabalhados, 
malgrado suas especificidades, encontram correspondentes sócio-afetivos na temática central do grupo e no contexto sócio-histórico em questão. A partir deste esquema, de forma opcional podem ser utilizados métodos de escrita autobiográfica (Niewiadomski, 2012), como recursos para impulsionar o processo de assimilação da trajetória social de cada sujeito e também para explorar as reflexões coletivas realizadas ao longo das discussões.

Em geral, após o resgate e reconstituição da história dos participantes, o Teatro-Fórum (Boal, 1975 ; Badache, 2015) e o Sociodrama (Moreno, 1978; Ancelin-Schutzenberger, 2003) são utilizados para explorar questões centrais, divergentes ou convergentes, que surgiram nas etapas ulteriores. Com o apoio do mediador e a partir dos pressupostos teórico-técnicos de ambas as abordagens, o grupo elenca situações conflituosas específicas (Viana Braz, 2019), a partir de suas vivências concretas no trabalho (por exemplo), para representá-las mediante a criação de um espaço cênico estruturado por um cenário de base. $\mathrm{O}$ improviso é colocado como elemento propulsor da criatividade e da liberdade do grupo. Ao final da encenação de cada vinheta, pela via do Sociodrama ou do Teatro-Fórum, reserva-se um momento de reflexão e análise coletiva. Cada ator é convidado a falar sobre seus sentimentos e dificuldades na representação de seu papel (ou papéis). Depois, uma vez que nem sempre todos os participantes envolvem-se na cena como atores, os espectadores expressam suas percepções, bem como as ressonâncias emocionais produzidas nas ações dramáticas. Ao mediador, cumpre estabelecer o fio condutor das reflexões, a fim de fomentar o debate sobre como as diferentes configurações dos cenários de base, bem como suas transformações, estariam mais ou menos vinculadas com as questões que surgiram nos trabalhos anteriores.

Cada participante é convidado a utilizar sua experiência pessoal para compreender fenômenos coletivos que tocam os demais integrantes do grupo. Alternam-se dinâmicas de expressão verbal e não verbal, de reflexões individuais e coletivas, de manifestações emocionais e análises racionais. De acordo com Gaulejac (1987), isso faz com que os sujeitos permaneçam em constante movimento, o que os permite vivenciar, interiorizar e incorporar as mudanças operadas no grupo. Ao revisitar sua história, o sujeito não consegue alterá-la, mas desvela-se possível modificar sua relação com ela. E é esse o movimento de construção de autonomia e de historicidade almejado nos GIP (Gaulejac, 1987).

Os GIP abarcam um trabalho de objetificação, isto é, o sujeito se distancia de sua própria história, situando-a no bojo de suas relações sociais, o que o permite relativizar sua singularidade, pois ela mesma é também produto de uma história atravessada pelo conjunto de elementos sócio-históricos inerentes ao grupo. Esse distanciamento facilita que o sujeito se perceba enquanto produto de uma cultura, época e classe social específica. Somente esse distanciamento, porém, não garante a efetividade do grupo. Faz-se necessário que essa objetificação se vincule à experiência subjetiva de cada indivíduo, de modo que ela deve ser fruto de expressões singulares, as quais permitem que o sujeito a interrogue e a coloque em questão. É, portanto, na dialética entre o psíquico e o social, entre a objetividade e a subjetividade, que os participantes dão sentido as questões comuns que perpassam a dinâmica grupal dos trabalhadores (Gaulejac, 1987). 


\section{Organidrama}

22 O Organidrama [3], outro dispositivo utilizado na Sociologia Clínica, foi desenvolvido por Gaulejac [4] nos anos de 1980 e 1990, a partir de intervenções realizadas em empresas públicas e privadas, de diferentes setores, cuja demanda se vinculava a necessidade de se trabalhar coletivamente conflitos e dinâmicas de sofrimento percebidas como recorrentes.

23 Após os anos 2000, esse dispositivo passou a ser usado sistematicamente em conjunto com os GIP. Construído especialmente como alternativa de intervenção no contexto laboral, conjuga a interação da lógica organizacional de uma organização com as vivências pessoais e coletivas do grupo. Uma vez que os conflitos nas organizações amiúde são também sintomas das contradições e paradoxos de sua própria lógica de funcionamento (Gaulejac, 2011), busca-se compreender suas origens sem reenviar a problemática para o nível estrito individual, mas colocando em questão os fenômenos sociais que o precedem. Como alternativa a orientações psicologizantes, o Organidrama traz em primeiro plano a dimensão emocional do trabalho real, interpretado singularmente, mas o colocando em integração com a lógica organizacional e determinismos sociais presentes em cada contexto.

24 A partir de técnicas provenientes da representação em jogos de papéis e assentado no trabalho sobre histórias de vida, no Organidrama se visa criar um espaço no qual os participantes do grupo experimentam situações sociais concretas, baseadas em cenários de base e cenas escolhidas. Diferentemente dos GIP, o Organidrama não parte de um tema geral. Em cada sessão do dispositivo, são os próprios sujeitos que escolhem os eixos a serem trabalhados.

Suas bases metodológicas e técnicas provêm do Sociodrama de Moreno (Moreno, 1978 ; Ancelin-Schutzenberger, 2003), do Teatro-Fórum (Boal, 1975; Badache, 2015) desenvolvido por Augusto Boal, bem como da análise dialética e da epistemologia da complexidade pagesiana (Pagès, 1968 ; 1986 ; 1993). Inserido na Sociologia Clínica, ao reunir distintas abordagens, esse dispositivo também não tem por finalidade a realização de uma terapia (como no sociodrama moreniano), nem é centrado na resolução de problemas de violência e dominação (embora eventualmente isso surja como questão), como é fundamentado o Teatro-Fórum (Vandevelde-Rougale, 2012). O foco é a compreensão dos mecanismos que influenciam as ações dos indivíduos, a partir de um trabalho de coconstrução cuja finalidade é conduzir o indivíduo a se questionar sobre suas vivências, escolhas, história e seus projetos futuros, confrontando-o com seus ideais e sua implicação, no registro existencial (Vandevelde-Rougale, 2012). A mudança tem caráter secundário. Isso não quer dizer que isso não ocorra, mas parte-se da premissa que a mudança baseada em uma compreensão superficial das contradições que atravessam a cena de trabalho pode eventualmente ser realizada, mas somente no plano dos comportamentos (Viana Braz, 2019). Se a compreensão e a implicação no Organidrama precedem à mudança, é porque as intervenções incluem também as dinâmicas de poder e investimentos psíquicos vinculados à própria dimensão estrutural das organizações.

Estruturalmente, o número de sessões no Organidrama varia sempre em função da demanda da organização e dos conflitos existentes. As sessões duram entre duas e três horas e são restritas entre 5 e 35 pessoas. A excedência desse limite dificulta a liberdade de expressão e a garantia da qualidade de escuta e atenção ao outro. $O$ mediador 
convida os participantes a encenar situações de trabalho produtoras de mal-estar ou que evidenciam conflitos recorrentes em seus cotidianos. A criatividade e espontaneidade, pilares do Sociodrama moreniano, constituem a espinha dorsal das improvisações realizadas.

Em termos práticos, o dispositivo é constituído por uma sequência de cenas representadas em três tempos fundamentais :

- Preparação: se inicia com a apresentação do dispositivo e de seus pressupostos teóricos e metodológicos, análogos aos GIP. Depois, formam-se subgrupos e cada grupo é instruído a discutir experiências pessoais de trabalho, vividas como conflituosas ou intensificadoras de sofrimento. Cada grupo deve escolher uma situação, a ser encenada diante de todos os demais, e se atribui a ela um título, na forma de interrogação (Vandevelde-Rougale, 2012).

- Improvisação teatral e análise : todos os grupos fazem suas encenações, baseadas nas premissas teórico-técnicas do Sociodrama e do Teatro-Fórum. Em cada situação representada é feito um trabalho de descrição e exploração das experiências emocionais e corporais vividas por cada participante. Discutem-se as relações entre as tensões encontradas nas situações encenadas, as contradições da lógica do funcionamento organizacional e a maneira como são vividas. Os subgrupos são convidados a refletir conjuntamente sobre cada situação evocada, de modo a compreender suas particularidades e lógicas de funcionamento. Trata-se do tempo da reflexão coletiva, da análise de conflitos e da tomada de consciência sobre os problemas encontrados (Vandevelde-Rougale, 2012).

- Ressurgimento : tempo reservado à exploração das ressonâncias emocionais, compreensões e questões suscitadas no dispositivo pelos participantes. É o tempo de retrospectiva das experiências vivenciadas. Integrando as dimensões corporais e emocionais das vivências suscitadas, a atribuição de sentido se dá mediante um trabalho de coconstrução sincrônica e recursiva, em que os participantes conjuntamente elaboram as hipóteses interpretativas para os conflitos evocados. Novos olhares e orientações comumente se direcionam para novos posicionamentos diante de situações conflituosas (Castro \& Guerrero, 2013). Nas organizações, esse é tempo da elaboração de alternativas de ações, com vistas a repensar a dinâmica organizacional e as relações laborais. A partir do trabalho realizado e com o apoio das propostas de Badache (2015) de síntese escrita, elaboram-se conjuntamente planos possíveis para mudar o curso dos conflitos emergentes e do sofrimento existente, seja no âmbito relacional, seja no âmbito dos processos e da gestão da organização.

28 As sessões de Organidrama são realizadas com um ou dois mediadores, com formação em Sociologia Clínica e cuja função consiste em manejar tensões emocionais emergentes nas cenas, bem como auxiliar na construção de hipóteses interpretativas. Ainda sobre o enquadre, o interventor deve esclarecer dois pontos aos participantes :

- Cada participante tem a liberdade de dizer ou não dizer, de se implicar mais ou menos. Parte-se da premissa nem forçar, nem reter. Isto é, sobretudo na mediação, devem-se buscar questionamentos que abram as portas (para a palavra), mas sem ceder ao desejo de forçá-las, com interpretações selvagens e invasivas (Gaulejac, 1987).

- Trata-se de trabalhar sobre os processos sociais (e não na forma de acompanhamento individualizado) e o protagonista da situação concreta elencada não pode realizar seu próprio papel na cena representada. Essa premissa se justifica, pois é importante que quem vivenciou concretamente a situação na cena de trabalho a represente por outro ponto de vista e mediante outro personagem. Além disso, os mediadores devem ser flexíveis ao enquadre. Conforme discorre Vandevelde-Rougale (2012), a sequência de ressurgimentos, por exemplo, só é possível quando a lógica temporal das situações trabalhadas se remete, no 
âmbito coletivo, à exploração das experiências individuais, a fim de reescrevê-las em uma óptica psicossocial. Igualmente, a temporalidade das etapas descritas pode ser modificada em razão das demandas e da lógica de funcionamento de cada grupo (Vandevelde-Rougale, 2012).

No Organidrama se subentende que o cotidiano laboral é produto da intersecção de problemáticas de ordem existencial (correlatas à história das pessoas), organizacional (vinculadas à gestão das organizações), social (determinadas pelas estruturas e normas sociais) e econômica (inerentes aos modos de produção e cenários político-econômicos) (Aubert \& Gaulejac, 1991). Logo, a compreensão do sofrimento de um trabalhador passa por uma análise dialética em termos de processos sociopsíquico-organizacionais, evitando a oposição entre indivíduo e organização. Para afirmar-se e existir socialmente, se o indivíduo produz a organização, ela inversamente também o produz, visando assegurar sua reprodução. É justamente em razão desse caráter intrínseco entre funcionamento psíquico e organizacional que não se trata indivíduo e organização como entidades opostas ou sobrepostas, mas interdependentes e interrelacionadas (Gaulejac et al., 2012).

\section{Trabalho reflexivo e emocional nos grupos : análise de um grupo de implicação e pesquisa}

De modo a elucidar como se opera o trabalho reflexivo e emocional nos grupos, será realizada neste tópico uma síntese sobre uma experiência de um Grupo de Implicação e Pesquisa (GIP), no qual também foi usado o Organidrama. Os participantes foram conhecidos na ocasião em que um dos autores deste estudo lecionava uma disciplina em um MBA voltado à Administração de Recursos Humanos. Como alguns profissionais demonstraram interesse na abordagem da Sociologia Clínica, lhes foi feito um convite para a realização de um grupo, cuja temática se intitulou "narrativas de vida e conflitos no trabalho". Por restrições de tempo e incompatibilidades de horários, os trabalhos foram condensados ao longo de duas jornadas diárias. No total de participantes, havia onze mulheres e um homem, de campos de atuação e idades variadas (entre cerca de 20 e 50 anos), mas que compartilhavam entre si o interesse na compreensão dos conflitos nas organizações.

\subsection{Primeiro dia}

31 No início da primeira jornada, foi feita uma explanação sobre o nascimento da Sociologia Clínica, dos GIP e se explicitou que o objetivo do trabalho era refletir sobre os enlaces entre as histórias de vida (individuais e coletivas) dos participantes e os conflitos enfrentados em suas vivências no trabalho. No plano metodológico, os seguintes pressupostos teóricos (Gaulejac, 2019) foram apresentados e aprofundados junto ao grupo :

- Vislumbra-se a superação da oposição entre mudança pessoal e mudança coletiva.

- trabalho se foca na articulação dinâmica entre os registros social, familiar e individual, mediante um trabalho sobre as emoções e sobre a reflexividade.

- Trata-se de um dispositivo que introduz a dimensão do vivido e do exercício da escuta sensível, sobretudo em relação a expressões de desejos, angústias e projeções. 
- Em relação às mudanças, parte-se de uma perspectiva compreensiva que busca mais alternativas do que soluções, a partir da vivência dos participantes.

- Os resultados do trabalho somente poderão ser apreendidos a posteriori, pois concebe-se uma abordagem progressiva e generativa de sentido.

- desenvolvimento exitoso desse processo depende da implicação e engajamento de todos os participantes.

32 Sobre o contrato psicológico, baseados em Gaulejac (1987) reiterou-se que ao longo dos trabalhos os participantes teriam a liberdade para colocar interrogações aos demais, mas que não deveriam ceder ao desejo de ultrapassar os limites dos indivíduos. Cabe sublinhar que o principal garantidor de que essa premissa seja cumprida e não saia do controle é o próprio mediador. Cumpre a ele fazer uma leitura do termômetro emocional dos grupos e intervir quando necessário (Gaulejac, 1987). Por outro lado, é preciso dizer que nas intervenções conduzidas pelos autores deste estudo nunca se presenciou nenhum tipo de interpretação selvagem ou posicionamento invasivo de algum participante.

33 Reforçou-se também que ninguém seria obrigado a compartilhar aspectos de sua vida que não se sentisse à vontade ou preparado a exprimir. Estabeleceu-se um pacto de confidencialidade e confiança acerca dos conteúdos trabalhados e todos se comprometeram a serem pontuais em relação aos horários de início e fim das jornadas. Os trabalhos se iniciariam às $08 \mathrm{~h}$ da manhã, seria feito um almoço das $12 \mathrm{~h}$ às $14 \mathrm{~h}$ e às 19 horas a jornada seria finalizada. Em ambos os períodos, também era realizada uma pausa de 15 minutos.

34 Depois, iniciou-se uma atividade de compreensão sobre as origens e significados dos nomes de cada participante. Partindo do pressuposto que os indivíduos são herdeiros das fantasias, projeções e sonhos de suas figuras parentais (Gaulejac, 1999), busca-se resgatar em quais condições e contextos se operou a escolha dos nomes dos sujeitos do grupo. Para além do sentido restrito e semântico dessa escolha, interessa compreender em que medida ela está relacionada com a construção de um projeto de vida cujas expectativas encontram-se no bojo de questões sociais e familiares. O nome, portanto, representa o primeiro elemento de ligação do sujeito com sua herança, em um processo de inserção social que se dá inclusive sem sua vontade, pois o ser humano é constituído pelo desejo do outro (Teixeira \& Hashimoto, 2005).

35 Essa atividade costuma ser bastante profícua ao trabalho de reflexividade sobre si. Alguns participantes não conhecem o enredo da escolha de seus nomes, outros têm ciência desse processo, mas ficam instigados a procurar mais informações a respeito. Nesse dia, especificamente, ocorreu um fato ilustrativo dessa dinâmica. Uma participante não sabia qual a origem de seu nome. No horário do almoço, telefonou para seus pais e pediu que a contassem como foi realizada essa escolha. Seu nome era produto da junção das primeiras sílabas dos nomes de seu pai e de sua mãe. Como não haviam chegado a um acordo conjunto, ambos encontraram nessa opção uma solução para mitigar suas divergências e conflitos. No trabalho seguinte de análise sobre sua trajetória social, a participante relatou que as principais lembranças e percepções que tinha de quando residia com seus pais envolviam situações de atritos e confrontos. Parece que o relacionamento entre eles sempre foi alimentado por brigas constantes, testemunhou. A integrante do grupo discorreu que costumava se colocar no meio das discussões familiares, mas que amiúde se sentia dividida, pois se via obrigada a assumir um lado, defendendo ora seu pai, ora sua mãe. A participante expressou ainda 
indagações sobre o quanto a escolha de seu nome traduzia, antes mesmo de seu nascimento, a dinâmica relacional de seus pais, o que por sua vez a colocava em uma posição ambígua e complexa.

36 Após os participantes dividirem suas reflexões sobre a saga da escolha de seus nomes, foi iniciado o trabalho sobre a análise de suas genealogias e trajetórias sociais. Apresentou-se o esboço do esquema da trajetória de vida (Figura I), os objetivos desse instrumento, assim como foi dada a cada pessoa uma cartolina e canetas esferográficas de variadas cores. Para que reconstruíssem suas histórias, foi definido um tempo de 40 minutos. Depois, todos os participantes colaram seus respectivos esquemas em uma lousa que havia no local onde o grupo era realizado [5] e ficaram dispostos como indicam as imagens abaixo.

Figura II : Grupo de Implicação e Pesquisa. Análise das trajetórias sociais

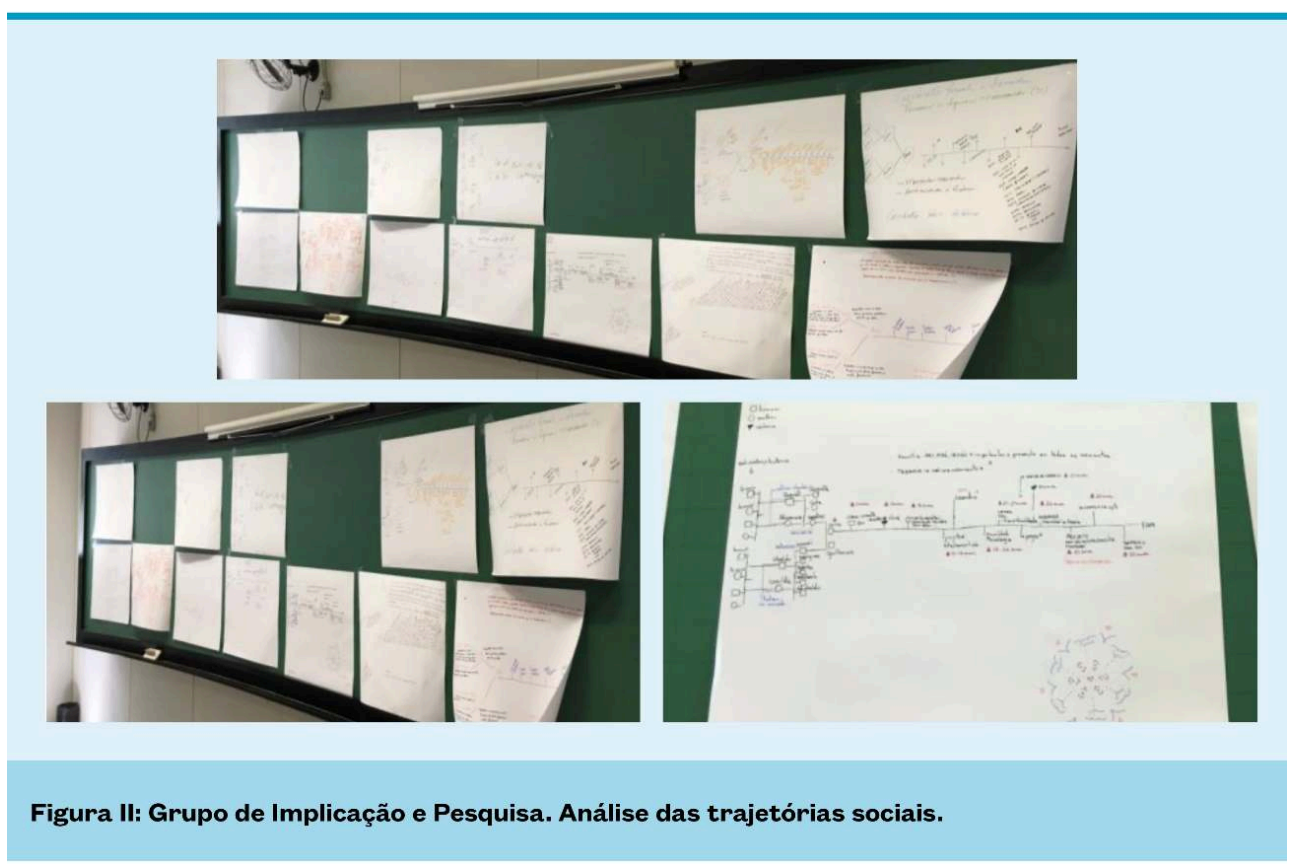

Figura II : Grupo de Implicação e Pesquisa. Análise das trajetórias sociais

37 Até o final do primeiro dia, o trabalho compreendeu a exploração das trajetórias de vida narradas individualmente pelos participantes. Realizou-se nesse processo, um movimento de vai-e-vem constante, que possibilitou ressignificar vivências singulares em articulação com análises coletivas. Abarcaram-se também nesse trabalho as reflexões e discussões sobre a formação dos respectivos projetos parentais e sobre como os principais momentos de escolhas e rupturas da vida dos participantes estavam ligados às escolhas profissionais e as maneiras com as quais encaravam seus conflitos. Não constitui foco desse estudo apresentar as histórias individuais dos membros do grupo, mas serão feitas algumas reflexões sobre questões comuns, que surgiram relacionadas ao plano social.

As primeiras pessoas que narraram suas trajetórias expressavam o sentimento de vergonha sobre suas histórias e conflitos sócio-familiares. Em suas genealogias, se impôs como imperativo a reprodução intrafamiliar de violências físicas e simbólicas, bem como de desentendimentos e traições em suas relações pessoais. Gradualmente, 
entretanto, a dinâmica grupal assumiu outros contornos. Ao passo que os demais também compartilhavam suas experiências, os participantes trouxeram uma discussão que perdurou por cerca de quarenta minutos. O que é uma família perfeita, afinal ? Ela existe? Essas foram interrogações disparadoras, que os levaram a refletir sobre o peso social do mito da familia perfeita. Há também nesse ponto uma dialética existencial em jogo. Gaulejac (1996) reconhece na vergonha um meta-sentimento, em função de sua múltipla dimensionalidade. Neste grupo, ela surgiu como produto de processos identitários e de subjetivação vividos como angustiantes, relacionados a situações de estigma, humilhação, exploração, precariedade material e desemprego. Ao passo que o indivíduo se constitui em relação aos outros e a si mesmo, a dinâmica sócio-afetiva emergente no grupo parece ter oferecido aos participantes uma identificação projetiva (Palmade \& Palmade, 2005), que resultou tanto na diferenciação em relação aos meios aos quais provinham como também os concedeu um sentido de pertencimento e segurança ontológica (Viana Braz, 2019).

39 Abriu-se, por conseguinte, um espaço de reflexão sobre as possibilidades de ressignificar violências humilhantes. No início do trabalho, algumas participantes trouxeram à tona sentimentos de inquietude, decepção e raiva, relacionadas à passividade de suas mães e avós em face de situações de violência e deslegitimação. Havia uma ambiguidade presente nas vivências relatadas. Ao mesmo tempo em que as culpabilizavam, as referiam como vítimas e pessoas centrais nas estruturas familiares. Ao trazer essas ressonâncias individuais para o nível coletivo, os membros do grupo discutiram sobre como a reprodução dessas relações estavam presentes em suas vidas. o papel ocupado pela mulher no mundo do trabalho surgiu em primeiro plano e as participantes trouxeram reflexões acerca de crenças e costumes, inerentes a suas dinâmicas relacionais, que legitimavam historicamente relações de dominação contraditórias.

40 Em termos metodológicos, o movimento relatado, de reflexão individual e coletiva, é elucidativo da postura compreensiva na abordagem clínica. Sempre que um sujeito atribui um novo significado às suas vivências, esse conhecimento modifica a consciência que tem de si mesmo (Sartre, 1960). Por isso, na Sociologia Clínica se fala em compreensão, descrição e não em explicação. Entende-se que a complexidade da dimensão humana não pode ser reduzida a processos inertes e explicativos da realidade em sua totalidade. Embora haja imperativos sociais e materiais que condicionam as escolhas das pessoas, eles são vividos e significados de forma particular. Rejeitam-se definições cristalizadas, universais e abstratas, pois se concebe que o sujeito é portador de consciência reflexiva, ator de sua própria história e não um mero produto de forças incontornáveis (Gaulejac, 1996). Se a Sociologia Clínica desde seu surgimento renunciou a ideia de construir uma metateoria explicativa global para os fenômenos sociais, é porque se apreende que nesse intento inevitavelmente às ciências sociais tornam-se deterministas, causais e objetivistas (Viana Braz, 2019). Logo, parte-se de uma abordagem dialética, a qual concebe a linguagem como vetor elementar da racionalização das vivências. A construção da historicidade do sujeito se opera na articulação entre individual e coletivo, subjetivo e intersubjetivo, pelo confronto com as contradições que lhe atravessam, mediante uma rede sucessiva de significações em constante mutação.

41 No caso das mulheres do referido grupo, não bastaria somente colocar em questão os determinantes sócio-históricos que condicionavam os posicionamentos de suas mães e 
avós. Antes disso, a análise de suas respectivas trajetórias permitiu um movimento de assimilação reflexiva, que passou pela compreensão da multiplicidade de vivências e posições ocupadas por essas figuras, como também pela reflexão sobre de que maneira a transmissão psíquica geracional influenciava suas escolhas, projeções e expectativas em seus relacionamentos afetivos.

\subsection{Segundo dia}

Iniciou-se a segunda parte da jornada, no dia seguinte, com um momento de ressurgimento. Reservou-se um tempo para que ressonâncias emocionais oriundas do trabalho realizado no dia anterior fossem colocadas no espaço do grupo (VandeveldeRougale, 2012). Destaca-se que o mediador é responsável nesse momento pela identificação de aspectos sensíveis trazidos pelos participantes. Esse tempo é fundamental no trabalho de implicação, tanto do interventor quanto dos demais membros do grupo.

43 Depois, prosseguiu-se a realização de uma síntese interpretativa dos pontos comuns que emergiram no grupo, relacionados à questão dos conflitos no trabalho. Novamente, a reprodução da forma como as figuras centrais das trajetórias dos participantes lidam com conflitos se tornou objeto de discussão. Pais, mães, irmãos, tios, chefes e colegas de trabalho foram trazidos à tona, sejam como modelos positivos, sejam como figuras associadas a repulsa e denegação. Em suma, os significantes centrais dessa reflexão diziam respeito a relações de dominação, de humilhação, a situações de instabilidade emocional e sentimentos de impotência diante de conflitos.

44 Encaminhou-se o trabalho à realização de uma sessão de Organidrama. Os participantes foram divididos aleatoriamente em dois subgrupos e cada um foi instruído a discutir vivências pessoais conflituosas e de sofrimento no trabalho. Depois, deveriam elencar uma situação para ser encenada e cada grupo escolheria um título para a cena, colocado na forma de interrogação. A distribuição de papéis era aberta, porém para que pudesse vivenciar a representação a partir da perspectiva de outro personagem, o protagonista da situação escolhida não poderia representar seu próprio papel.

45 Na mediação dos grupos, percebe-se que o trabalho de aquecimento antecedente à dramatização é de suma importância para que os participantes representem seus papéis com mais liberdade e naturalidade. É comum nesse contexto que os trabalhadores não saibam do que se trata o jogo de papéis e precisem de estímulos para aguçar suas percepções corporais. Afora as tradicionais atividades de aquecimento oferecidas pela teoria moreniana, resultados profícuos foram obtidos pelos pesquisadores com a inserção de jogos de improviso nessa etapa. Por incluírem ingredientes como a criatividade e o humor, esses recursos são utilizados nos referidos grupos para despertar nos participantes a espontaneidade e criar uma atmosfera de abertura às vivências da dramatização.

46 No Sociodrama de Moreno (Moreno, 1978 ; Ancelin-Schutzenberger, 2003), o mediador (ou diretor) pode interromper o jogo de representação de papéis quando julgar pertinente. Com base no Teatro-Fórum de Boal (1975), após a primeira dramatização (da cena-modelo) no Organidrama também se deixa aberta aos espectadores a possibilidade de "congelar" as cenas, para que possam fazer sugestões de mudanças, assumindo o papel de algum personagem e lhe atribuindo eventualmente outras 
atitudes, comportamentos ou características de personalidade. À título de ilustração, apresenta-se adiante uma cena representada por um dos grupos.

\section{Qual a falta que faz o ponto?}

$471^{\underline{a}}$ ação : Pedro (todos os nomes são fictícios), trabalhador da fábrica, vai ao encontro de seu supervisor (Ricardo) e lhe relata inconformado que descontaram um dia em sua folha de pagamento, sem nenhuma justificativa, pois estava trabalhando na empresa no referido dia. Ricardo, atarefado, diz que não pode fazer nada e que Pedro deveria resolver a situação no departamento de Recursos Humanos (RH). $\mathrm{O}$ trabalhador então exclama : "só podia ser mesmo, vou lá agora !".

$2^{a}$ ação: No departamento de RH, Carla, responsável pelo setor e, portanto, pelo fechamento do ponto e pagamento dos funcionários, sentada em sua mesa conversava com Emerson, técnico de segurança do trabalho na empresa. Havia também na cena Augusta, a auxiliar de serviços gerais que fazia a limpeza do setor. Furioso, Pedro entra sem avisar no departamento e questiona incisivamente Carla :

Pedro - Que confusão você aprontou dessa vez ? Por que você descontou meu dia na semana passada?

Carla - Como assim descontei seu dia na semana passada ? O que você tá falando ?

Pedro - Tem um dia a menos na minha folha de pagamento. Como assim ? Eu trabalhei o dia inteiro e você desconta?

Carla - Primeiro, vamo abaixar o tom, vamo abaixar a voz, você não pode entrar na minha sala assim...

Emerson - Gente, calma...

Carla - Eu segui todo o procedimento padrão da empresa. Você conferiu o registro do seu ponto?

Pedro - Não, isso aí é você que tem que fazer ! Eu tava aqui e não quero nem saber.

Carla - Você não sabe conversar, não tem condições de falar com você...

Pedro - Você é burra? (Pedro dá um tapa na mesa de Carla) Resolve isso pra mim, não posso perder esse dinheiro.

Carla, já exaltada, se levanta de sua cadeira.

Carla - Eu não sou obrigada a passar por isso e ouvir esse tipo de desrespeito. Não tem condições. Não aceito esse tipo de ofensa.

Carla e Pedro começam a discutir e não é mais possível ouvir o que cada um está dizendo.

Emerson entra no meio dos dois e fala ainda mais alto: 
Emerson - Vamos resolver isso depois. Agora não dá. Vocês estão fora de si. Pedro, sai daqui ! Depois resolve !

Pedro então se retira furioso da sala e Carla começa a chorar. Augusta, que ficara paralisada com sua vassoura nas mãos durante a discussão, lhe oferece um copo de água.

$3^{a}$ ação: Horas depois, Ricardo, o supervisor, é chamado no RH e se reúne com Carla. Para fins de contextualização, na empresa os funcionários da fábrica faziam os registros manuais de seus pontos (pois trabalhavam em plantas variadas, dependendo do momento do processo produtivo). No fim do mês, essas folhas de registros eram validadas pelo gestor, que as entregava ao RH e que por sua vez passava as informações para um sistema eletrônico da empresa. Pedro, no fatídico dia se esquecera de assinar sua folha de ponto e o erro passou despercebido por Ricardo. O problema, contudo, agora era outro.

Carla - Ricardo, não dá pra admitir esse tipo de situação. Isso que aconteceu aqui é inadmissível. Você não tem controle da sua equipe.

Ricardo - Eu não tinha como saber o que tava acontecendo, senão teria feito alguma coisa.

Carla - Fui humilhada aqui na frente do Emerson. Como responsável pelo RH a gente não pode admitir isso. Não posso abaixar a cabeça, senão vão pensar que isso aqui é uma zona. Temos que decidir o que vamos fazer com o Pedro.

Ricardo - Eu errei, eu assumo, mas o comportamento dele não tá alinhado com a empresa. $\mathrm{O}$ cara é bom, mas não tem nem dois anos que tá aqui. Vamos ter que dispensar, senão perco a mão com a equipe. Vão achar que todo mundo pode desequilibrar.

Após mais algum tempo de discussão, Ricardo e Carla decidem pela demissão de Pedro, mas sem justa causa, para evitar possíveis imbróglios e passivos trabalhistas.

\section{Fórum}

Finalizada a dramatização da cena-modelo, houve um momento de descontração. Os espectadores aplaudiram os atores, começaram a rir e a conversar uns com os outros. Iniciou-se, então, uma discussão sobre como a cena transcorreu e como foi percebida pelos demais membros do grupo. Nesse primeiro momento, abriu-se no fórum a possibilidade de que os espectadores pudessem substituir os personagens, exceto Pedro. Essa escolha foi feita na mediação para que os participantes pudessem exercitar suas capacidades reflexivas em relação às alternativas postuladas. Se Pedro fosse trocado já no início, se esgotariam as possibilidades de explorar as cenas conflituosas e situações de tensão, pois bastaria que o trabalhador fosse representado como um personagem mais sereno e calmo.

51 As dramatizações procedentes tiveram variadas roupagens. Primeiro outros participantes assumiram os papéis de Carla e Ricardo. O supervisor entrou na sala com 
uma postura conciliadora, tentando acalmar Pedro, mas sua tentativa não foi exitosa. A personagem de Carla se focou no problema de Pedro, porém demonstrou um posicionamento ainda mais impositivo, o que desencadeou um novo descontrole. A cena foi interrompida por um espectador, que se prontificou a substituir Emerson. Quando as discussões se tornaram novamente calorosas, houve outra paralisação. Carla foi novamente trocada, dessa vez representada com mais serenidade e equilíbrio. Depois, Augusta também entrou em cena de forma mais ativa, colocando-se em defesa da profissional de RH. Os participantes do grupo somente conseguiram chegar à terceira ação quando Pedro foi substituído. Como as tensões foram mitigadas, Ricardo assumiu sua responsabilidade ao não rever com rigor a folha de ponto de seu subordinado e, junto a Carla, foi decidido que o trabalhador receberia uma advertência formal por sua intransigência e falta de profissionalismo. Como se entendeu que a cena já havia se esgotado, o fórum foi encerrado.

\section{Ressurgimento e análise}

52 Na próxima etapa, conduziu-se no grupo uma exploração sobre as vivências de cada personagem que dramatizou a cena-modelo. Os trabalhos realizados passaram pelas seguintes interrogações : a cena se passou com quem na realidade? A protagonista da cena concreta ocupou o papel de qual personagem ? o que sentiu ao ver outra pessoa fazer seu papel? Qual a percepção e sentimento experimentados por cada participante durante as ações? Como isso reverberou nos registros de suas emoções e corporal ? E os espectadores, quais percepções tiveram ao ver a cena "de fora", com outros olhares?

53 Foram também aprofundadas as experiências dos espectadores que fizeram parte da dramatização do fórum, assim como se ouviram os relatos daqueles que não entraram em cena em nenhuma ocasião. Em seguida, partiu-se para um trabalho de reflexão coletiva acerca das situações de conflitos e das alternativas de ação propostas.

54 Quanto à análise coletiva, alguns elementos se revelaram relevantes nessa seção de Organidrama. No registro econômico, identificaram-se problemas trazidos em cena relacionados a uma perda concreta, evidenciada pelo prejuízo financeiro de Pedro. Não há informações suficientes para avaliar qual o grau desse déficit, mas pela reação intempestiva do trabalhador, parece que lhe fora bastante caro.

55 A cena reflete também a lógica de uma estrutura social e organizacional específica. Ricardo, atarefado e pressionado por inúmeras demandas, não encontra recursos para oferecer uma escuta sensível a Pedro. Ao minimizar o problema trazido pelo funcionário, incorre no equívoco de terceirizar sua responsabilidade ao departamento de RH. Se Pedro chega ao setor rompendo com a dinâmica hierárquica da organização, em contraposição o mesmo não ocorre com Augusta. Auxiliar de limpeza, a funcionária responde às imposições das estruturas sociais e organizacionais na forma de passividade e mutismo, como se não fosse permitido sair de sua posição para se envolver em problemas alheios. Já Emerson, parece se sentir impotente na situação. No início fica calado, para não ser incluído na rede de conflitos da empresa, mas quando a situação foge do controle assume um posicionamento mais ativo e interrompe os desentendimentos.

56 A escolha do título (qual a falta que faz o ponto?) pelos participantes parece também certeira e providencial, pois reflete as contradições da dinâmica organizacional e seus efeitos no registro existencial, das vivências dos trabalhadores. Todos os conflitos são 
desencadeados por sucessivos problemas ligados aos dispositivos de controle e prescrição (Gaulejac \& Hanique, 2015) da empresa (os registros manuais de ponto, a validação e assinatura do gestor e a transposição dessas informações para um software de gestão). Todavia, mesmo quando esse processo falha, ele não é questionado em nenhuma dessas instâncias. Ao contrário, busca-se encontrar nos indivíduos os culpados. Ricardo menciona que não pode fazer nada, Pedro responsabiliza Carla (Qual confusão você aprontou dessa vez ?), que rebate dizendo que seguira todo o procedimento padrão da empresa. Nessa cena, temos uma elucidação fecunda de um paradoxo organizacional (Gaulejac \& Hanique, 2015), cujo conflito produzido pelos próprios procedimentos da empresa culmina na culpabilização do trabalhador e na individualização do sofrimento. A despeito do destempero emocional de Pedro, não surpreende que nesse contexto os trabalhadores assumam atitudes defensivas, como se fosse preciso antes de tudo se colocar em posição de exterioridade diante da iminência de um conflito. Quando essas tentativas fracassam, consequentemente as discussões saem da esfera organizacional e atingem o nível pessoal das relações entre os trabalhadores, evidenciados em várias expressões : Vocêe é burra ? Você não sabe conversar. Vocês estão fora de si. Você não tem controle da sua equipe.

57 Pode-se explorar no Organidrama as múltiplas faces dos conflitos representados no grupo, compreendidos mediante a articulação dialética de registros econômicos, sociais, organizacionais e existenciais. As dramatizações condensam os conflitos e convidam os sujeitos a pensarem alternativas a partir de perspectivas contrárias à culpabilização e à psicologização das contradições organizacionais (Viana Braz, 2019). Esse processo, no entanto, só é possível porque na abordagem clínica o trabalho emocional é intrincado à experiência e à reflexividade (Gaulejac, 1999). Por isso, ao contrário do sociodrama moreniano, no Organidrama não se buscam fenômenos catárticos. Reflexão e emoção são complementares, não se restringe a enquadramentos individualizados e se analisa a pluralidade de significações sociopsíquicas que surgem nas dramatizações (Castro, 2019).

58 Depois que foram finalizadas as duas cenas apresentadas pelos grupos, a última hora da jornada foi dedicada à realização de uma síntese interpretativa sobre os trabalhos realizados. As relações de dominação, humilhação e sentimentos de impotências diante de situações conflituosas que haviam surgido nas narrativas de vida dos participantes foram identificadas nas dramatizações. As vivências individuais e reflexões coletivas, nessa óptica psicossocial ofereceram aos sujeitos do grupo subsídios para discutirem alternativas de ação no trabalho que não fossem produtoras de violências.

59 Por fim, abriu-se um espaço para que os participantes fizessem observações e comentários relacionados ao dispositivo de intervenção como também à avaliação de sua participação. A partir das proposições de Badache (2015), indica-se também que seja solicitado aos participantes que enviem por email uma reflexão sobre o trabalho realizado. Após receber todos os textos, pode ser feita uma compilação em um único material (sem identificação de autoria), à ser encaminhada para todos os membros do grupo. Embora essa proposta não tenha um caráter obrigatório, a maior parte dos sujeitos se empenha nesse trabalho de implicação, de modo que os retornos recebidos costumam ser substancialmente enriquecidos de sentido. 


\section{Considerações finais}

Na primeira parte deste estudo, foi realizada uma incursão pelos pressupostos teóricos e metodológicos dos GIP e do Organidrama. Depois, a partir da apresentação de um exemplo prático, seus respectivos enquadres, condições e diferenciais foram explicitados. Como dispositivos de pesquisa e ação, ambos os instrumentos dão condições para que o pesquisador possa intervir no mundo do trabalho considerando as estruturas coletivas e jogos de poder nas organizações. É reforçada a necessidade de compreender os cenários laborais de acordo com a perspectiva clínica da complexidade, incluindo ingredientes como a historicidade, as narrativas de vida, as emoções genuínas (inclusive as consideradas ameaçadoras) e as angústias. Tratar de fato os conflitos implica sair do paradigma da imediatidade e assumir que para mudar é preciso abandonar posições maniqueístas e metodologias prescritivas (Vandevelde-Rougale, 2012). Por meio da intervenção em Sociologia Clínica, é possível compreender o indizível, o não-dito e as contradições estruturais que permeiam os conflitos nas organizações de trabalho.

61 As técnicas existentes nos dispositivos da Sociologia Clínica auxiliam o pesquisador em ciências sociais a dar forma e a direcionar suas intervenções, todavia o que assegura o êxito de suas ações são os pressupostos teóricos e metodológicos que alicerçam a abordagem clínica (Gaulejac, 2019). É a partir da escuta sensível, direcionada à compreensão das emoções, sofrimentos e representações, oriundas das vivências dos trabalhadores, que se torna possível desenhar propostas de intervenção mais complexas e integrativas, no âmbito da resolução dos conflitos sócio-organizacionais e existenciais nas organizações, sejam públicas, sejam privadas. Igualmente, no trabalho de mediação grupal a implicação é indissociada da responsabilidade, da empatia e da escuta sensível, o que torna fundamental que o interventor passe por uma formação teórico-prática sólida, que lhe habilite a trabalhar com prudência, para que os ânimos emocionais e os conflitos não saiam do controle e não gerem prejuízo para os trabalhadores (Viana Braz, Casadore \& Hashimoto, 2020).

Sem desconsiderar a dimensão sócio-histórica do trabalho e a materialidade das estruturas organizacionais, atua-se no plano intersubjetivo e por meio de ressonâncias emocionais se busca a exploração de diferentes aspectos sociais e coletivos, inerentes aos conflitos suscitados na dinâmica grupal. A partir da contextualização de cada história de vida e da produção coletiva de hipóteses interpretativas, a análise de conflitos psíquicos e sociais relacionados ao trabalho é elaborada recursivamente na abordagem clínica (Gaulejac, 1996). Na tentativa de evitar tanto a individualização do sofrimento como a psicologização das contradições sociais, considera-se que problemáticas individuais e sócio-organizacionais imbricam-se irredutivelmente a uma dimensão coletiva, que exige de qualquer interventor uma postura analítica compreensiva e crítica.

Sobre as fragilidades e limites destes dispositivos, variadas vezes os pesquisadores deste manuscrito se serviram do Organidrama de forma isolada nas organizações, utilizandoo inclusive de maneira pontual em intervenções breves. Como as iniciativas voltadas ao desenvolvimento dos trabalhadores e a gestão de conflitos nas organizações são conduzidas majoritariamente segundo uma perspectiva normativa e pedagógica, o Organidrama se revela um dispositivo diferenciado, que rompe com essa lógica hegemônica ao permitir que se trabalhe a partir do vivido dos sujeitos, articulando os 
níveis individual e coletivo, das emoções e da reflexividade. Em organizações fechadas, públicas como privadas, assim como em grupos abertos, foi observada a viabilidade desse dispositivo e reconhecido nele um potente veículo de transformação social.

A utilização dos GIP com grupos abertos se revelou igualmente profícua. Nestas situações, os laços estabelecidos entre os participantes não passam pela circunscrição de um único enquadramento organizacional, mas se constroem no decorrer do trabalho. Como são as pessoas que procuram o grupo e a demanda surge de maneira espontânea, os processos defensivos são minimizados, a implicação no trabalho é mais expressiva e a dinâmica socioafetiva grupal tende a ser mais aberta e heterogênea, o que facilita a mediação.

Para que os GIP sejam utilizados em organizações fechadas, é preciso que o interventor faça um trabalho prévio de análise sólida das dinâmicas socioafetivas dos diferentes grupos, bem como compreenda o nível de sua inserção institucional (a posição que ocupa na organização) e se certifique de que se estabeleceram laços de confiança entre os trabalhadores. Conforme sublinham Viana Braz, Casadore e Hashimoto (2020), é preciso ter responsabilidade, pois via de regra quando o grupo é finalizado o interventor vai embora, mas os trabalhadores permanecem na organização. Não se pode incorrer no erro de produzir espaços de expressão de conflitos e de exposição de histórias de vida que fogem ao controle do interventor, o que pode culminar na intensificação da hostilidade institucional e no fomento de relações transferenciais marcadas pela persecutoriedade (Viana Braz, Casadore e Hashimoto (2020). Em cenários onde exacerba-se a desconfiança, a rivalidade e a hostilidade, não se indica a utilização dos GIP sem um trabalho precedente, cuja finalidade é sedimentar a construção de espaços de proteção e confiança, para que seja possível intervir com maior profundidade.

66 Mais do que as condições de enquadre e de seu leque de técnicas, a espinha dorsal dos dispositivos de pesquisa e intervenção em Sociologia Clínica é constituída justamente por seus pressupostos teóricos e metodológicos. Este ponto é importante, pois é ele que garante que o pesquisador esteja precavido para que não haja a instrumentalização do trabalho com as abordagens biográficas. Seja a organização pública, seja privada, independentemente do setor de atuação, é preciso que o pesquisador compreenda sua estrutura de funcionamento e faça avaliações preliminares, de maneira a garantir que o propósito do grupo não seja dissimulado (caso se faça uso do dispositivo) e tampouco que instâncias decisórias ou os próprios trabalhadores não usem o espaço dos GIP para inibir ou manipular seus pares, de forma nociva e perversa. De todo modo, aprende-se também com a prática que quando a proposição do GIP ocorre de forma prematura, dificilmente a operacionalização do grupo é consumada. Nesses casos, há uma desimplicação e um mutismo que cumpre função defensiva contra possíveis situações ameaçantes e que impedem o andamento dos trabalhos.

67 À guisa de fechamento, cumpre salientar que o presente trabalho não tem por finalidade a criação de protocolos experimentais, como é feito comumente nas ciências naturais. Pretende-se que os exemplos discutidos sirvam como modelos e referências, de modo a inspirar pesquisadores a construir suas próprias intervenções. Espera-se que o leitor tenha encontrado pistas interpretativas que podem ser utilizadas da forma como achar mais adequada, desde que sejam seguidos os princípios que fundamentam a escuta do interventor orientado pela Sociologia Clínica. 
68 fronteiras entre trabalho e não trabalho são cada vez mais difusas. Por isso, talvez seja limitado pensar em qualquer forma de intervenção complexa que somente considera o trabalhador em sua relação com a organização na qual está inserido, como se ele fosse um objeto fragmentado. 0 funcionamento psíquico não é segmentado. Investe-se na potencialidade do Organidrama e dos Grupos de Implicação e Pesquisa, portanto, pois eles parecem abrir espaço para a superação das dicotomias mente e corpo, pensamento e ação, eu e outro, subjetivo e objetivo, consciência e matéria.

No cenário de trabalho atual de nossa sociedade, parece haver uma tendência à reificação do humano e à humanização de coisas inertes e abstratas (Gaulejac \& Hanique, 2015; Vandevelde-Rougale, 2012). O mercado e as organizações são antromorfizados e passam a ser tratadas como se tivessem necessidades próprias. 0 trabalhador, nessa perspectiva é visto como uma peça, que deve se colocar a serviço de necessidades dadas como instituídas e inquestionáveis (Viana Braz, 2019). Os dispositivos de pesquisa e intervenção da Sociologia Clínica indicam os caminhos de tensionamento dessa lógica e permite o investimento na potencialidade de transformação social dos sujeitos. Decerto que limites e impasses são sempre colocados nesse percurso. Não existem mudanças e resultados ideais, mas na abordagem clínica abre-se um espaço para a ampliação de um campo de possibilidades em que o porvir pode ser disruptivo, para além de condicionantes sociais e de ações passadas.

\section{BIBLIOGRAFIA}

Ancelin-Schutzenberger, A. (2003). Le Psychodrame. Paris : Payot.

Aubert, N., \& Gaulejac, V. (1991). Le coût de l'excelence. Nouvelle Édition. Paris : Éditions du Seuil. Badache, R. (2015). De l'improvisation à l'écriture. Utilisation de l'écriture dans la méthode du théâtre institutionnel. Vie Sociale, 1(9), 81-87. https://doi.org/10.3917/vsoc.151.0079

Boal, A. (1975). Jogos para atores e não atores. São Paulo : Cosac Naify.

Castro, F.J.G. (2019). Organidrame. In A. Vandevelde-Rougale, \& P. Fugier. (Dirs.), Dictionnaire de Sociologie Clinique. (pp. 442-444). Toulouse : Érès.

Castro, F.J.G., \& Guerrero, P. (2013). L'organidrame : um dispositif d'intervention et recherche em sociologie clinique. In V. Gaulejac, F. Giust-Desprairies, \& A. Massa, (Dirs.), La recherche clinique en sciences sociales. (pp. 219-236). Sociologie Clinique. Toulouse : Érès.

Gaulejac, V. (1987). La névrose de classe. Paris : Éditions Payot \& Rivages.

Gaulejac, V. (1996). Les sources de la honte. Nouvelle édition. Sociologie Clinique. Paris : Desclée de Brouwer.

Gaulejac, V. (1999). L'histoire en héritage : roman familial et trajectoire sociale. Paris : Éditions Payot \& Rivages.

Gaulejac, V. (2011). Travail, les raisons de la colère. Paris : Éditions du Seuil. 
Gaulejac, V. (2019). Epistémologie de l'intervention Socioclinique. In A. Vandevelde-Rougale, \& P. Fugier. (Dirs.), Dictionnaire de Sociologie Clinique. (pp. 252-256). Toulouse : Érès.

Gaulejac, V., Hanique, F., \& Roche, P. (2012) (Dirs.). La sociologie clinique : enjeux théoriques et méthodologiques. Toulouse : Érès.

Gaulejac, V., \& Hanique, F. (2015). Le capitalisme paradoxant : un système qui rend fou. Paris : Éditions du Seuil.

Lhuilier, D. (2011). Filiações teóricas das clínicas do trabalho. In P.F. Bendassolli, \& L.A.P. Soboll. (2011) (Dirs.), Clínicas do Trabalho: Novas perspectivas para compreensão do trabalho na atualidade. (pp. 22-47). São Paulo : Atlas.

Moreno, J.L. (1978). Psicodrama. São Paulo : Cultrix.

Niewiadomski, C. (2012). Recherche biographique et clinique narrative : entendre et écouter le sujet contemporain. Sociologie Clinique. Paris : Érès. https://doi.org/10.3917/eres.niewi.2012.01

Nunes, C.G.F., \& Silva, P.H.I. (2018). A Sociologia Clínica no Brasil. Revista Brasileira de Sociologia, 06(12), 181-199. http://dx.doi.org/10.20336/rbs.239

Pagès, M. (1968). La vie affective des groupes. Esquisse d'une théorie de la relation humaine. Paris : Dunod.

Pagès, M. (1986). Trace ou sens. Le système émotionnel. Québec : Hommes et Groupes Editeurs.

Pagès, M. (1993). Psychotérapie et complexité. Paris : Desclée de Brouwer.

Palmade, G., \& Palmade, J. (2005). Identificação. In J. Barus-Michel, E. Enriquez, \& A. Lévy. (Dirs.), Dicionário de Psicossociologia. (pp. 110-124), Lisboa : Editora Climepsi.

Sartre, J.P. (1960). Critique de la raison dialectique. Bibliothèque des idées. Paris : Gallimard.

Takeuti, N.M. (2009) Desafios da abordagem socioclínica e biográfica no contexto sociocultural e político brasileiro. In N.M.Takeuti, \& C. Niewiadomski. (Dirs.), Reinvenções do sujeito social : teorias e práticas biográficas. (pp. 74-94). Porto Alegre : Sulina.

Teixeira, M.A.R., \& Hashimoto, F. (2005). Família e escolha profissional : a questão espacial, temporal e o significado dos nomes. Pulsional : revista de psicanálise, 1(182), 63-73.

Turato, E.R. (2003). Tratado da metodologia da pesquisa clínico-qualitativa. Petrópolis : Vozes.

Vandevelde-Rougale, A. (2012). L'organidrame ou organiscope : un dispositif clinique pour approcher la complexité des organisations. Interrogations, 1(15), 01-07.

Viana Braz, M. (2019). Paradoxos do Trabalho : as faces da insegurança, da performance e da competição. Curitiba : Appris.

Viana Braz, M., Casadore, M. M., \& Hashimoto, F. (2020). Intervenção em Psicossociologia : a construção da escuta e a implicação nas organizações. Psicologia em Estudo, 25(1), 1-15. https:// doi.org/10.4025/psicolestud.v25i0.48468

\section{NOTAS}

1. A título de exemplificação, estas premissas são baseadas no grupo Romance familiar e trajetória social. A depender do grupo, entretanto, algumas dessas estruturas podem ser alteradas.

2. Essas são questões norteadoras. Na prática, em vários momentos essas construções podem ser alteradas, contanto que não perca a substância de seus significados. 
3. O nome Organidrama é produto da junção das palavras Organograma (Organigrame) e Sociodrama (Sociodrame).

4. Embora o Organidrama tenha sido criado por Gaulejac, é curioso notar que o autor ainda não publicou nenhum texto que trata especificamente desse dispositivo. Ao interrogá-lo sobre esse fato, Gaulejac testemunhou que há anos começara um esboço desse projeto, mas que por contingências da vida o deixara de lado. Em seu próximo livro (ainda em fase de construção), contudo, haverá um capítulo que terá como espinha dorsal o trabalho operado em algumas sessões de Organidrama em uma organização.

5. 0 grupo foi feito em uma universidade, que cedeu o espaço aos pesquisadores

\section{RESUMOS}

A Sociologia Clínica é marcada pelo compromisso de pesquisadores na construção de ações contrárias à culpabilização e à individualização das contradições existentes no mundo do trabalho. Neste contexto, buscou-se compreender os pressupostos metodológicos e técnicos de dois dispositivos de pesquisa e intervenção da referida abordagem (os Grupos de Implicação e Pesquisa e o Organidrama), de modo explorá-los como instrumentos para análise dos conflitos vivenciados no trabalho em nossa sociedade. $O$ método se baseou em abordagem qualitativa, transversal e descritiva. O estudo se inscreveu na modalidade de pesquisa em serviço e se estruturou mediante a produção de conhecimentos oriunda das atividades profissionais dos pesquisadores. Conclui-se o estudo com a explicitação dos diferenciais dos dispositivos, ligados às possibilidades de se trabalhar coletivamente fenômenos de ordem familiar, social e existencial, mas também políticos, ideológicos e gestionários engendrados nos contextos de trabalho dos sujeitos.

La Sociología Clínica se caracteriza por el compromiso de los investigadores en la construcción de acciones contrarias a la culpabilización e individualización de las contradicciones existentes en el mundo del trabajo. En este contexto, se buscó comprender los soportes metodológicos y técnicos de dos dispositivos de investigación e intervención en Sociología Clínica (los Grupos de Implicación e Investigación y el Organidrama), para explorarlos como instrumentos de análisis de los conflictos vividos en el trabajo en nuestra sociedad. El método se basó en un enfoque cualitativo, transversal y descriptivo. El estudio se inscribió en la modalidad de investigación en servicio y se estructuró a través de la producción de conocimiento a partir de las actividades profesionales de los investigadores. Se concluye el estudio con la explicación de los diferenciales de los dispositivos, vinculados a las posibilidades de trabajar colectivamente los fenómenos familiares, sociales y existenciales, pero también políticos, ideológicos y gerenciales engendrados en los contextos laborales de los sujetos.

La sociologie clinique est caractérisée par l'engagement des chercheurs dans la construction d'actions qui mettent en cause la culpabilisation et l'individualisation face aux contradictions existantes dans le monde du travail. Cette étude a eu pour but de comprendre les démarches méthodologiques et techniques de deux dispositifs de recherche et d'intervention de la sociologie clinique (les Groupe d'Implication et de Recherche et l'Organidramme), afin de les analyser comme des outils de recherche sur le monde du travail contemporain. La méthode s'est basée sur une approche qualitative, transversale et descriptive. L'étude a été inscrite dans la modalité de 
recherche en service et a été structurée par la production de connaissances issues des activités professionnelles des chercheurs. L'étude a été conclue en explicitant les différentiels des dispositifs, liés aux possibilités de travailler collectivement sur des phénomènes familiaux, sociaux et existentiels, mais aussi politiques, idéologiques et managériaux engendrés par les contextes de travail des sujets.

Clinical Sociology is characterized by the commitment of researchers to the construction of actions contrary to the logic of culpability and the individualization of the existential contradictions in the world of work. In this context, the purpose of this study is to understand the methodological and technical supports of two research and intervention devices in Clinical Sociology (the Implication and Research Groups and the Organidrame), in order to explore them as instruments for analyzing the conflicts experienced at work in our society. Through a qualitative, transversal, and descriptive approach, this study is part of the in-service research modality, starting from the production of knowledge from the professional activities developed by the researchers. The paper concludes with an explanation of the differentials of the devices, linked to the possibilities of working collectively on family, social and existential phenomena, but also political, ideological, and managerial ones engendered in the subjects' work contexts.

\section{ÍNDICE}

Mots-clés: sociologie clinique, organidrame, groupe d'Implication et de recherche, recherche et intervention, intervention au travail

Palabras claves: sociología clínica, organidrama, grupo de implicación e investigación, investigación e intervención, intervención laboral

Palavras-chave: sociologia clínica, organidrama, grupo de implicação e pesquisa, pesquisa e intervenção, intervenção no trabalho

Keywords: clinical sociology, organidrama, implication and research group, research and intervention, intervention at work

\section{AUTORES}

\section{MATHEUS VIANA BRAZ}

Universidade do Estado de Minas Gerais (UEMG). Av. Paraná, 3001 - Jardim Belvedere I, CEP

35501-170, Divinópolis, Minas Gerais, Brasil. mvianabraz@gmail.com

\section{FRANCISCO HASHIMOTO}

Universidade Estadual Paulista (UNESP). Av. Dom Antônio, 2100 - Parque Universitario, CEP 19806-900, Assis, São Paulo, Brasil. franciscohashimoto@gmail.com 